\title{
PENDIDIKAN ISLAM BERKEMAJUAN \\ DALAM PEMIKIRAN HAEDAR NASHIR
}

\section{Sarno Hanipudin}

STAI Sufyan Tsauri Majenang

\section{Ahmad Raviki}

STAI Sufyan Tsauri Majenang

Abstract: This research examines the Concept of Advanced Islamic Education in the View of Haedar Nashir. The focus of the research that was reviewed is how Haedar Nashir views the concept of Advanced Islamic Educators. This type of research is library research which is a pure library research. Thus the collection of data in this study is to use documentation methods that look for data on things or variables in the form of records such as books, magazines, documents, articles, words, daily minutes, meeting notes and so on.

Keywords: Advanced Islamic Education, Haedar Nashir.

Abstrak : Penelitian ini mengkaji tentang Konsep Pendidikan Islam Berkemajuan Dalam Pandangan Haedar Nashir. Fokus Penelitian yang dikaji yaitu Bagaimana Pandangan Haedar Nashir terkait konsep Pendidika Islam Berkemajuan. Jenis penelitian ini adalah library research yaitu suatu penelitian kepustakaan murni. Dengan demikian pengumpulan data dalam penelitian ini adalah menggunakan metode dokumentasi yang mencari data mengenai hal-hal atau variabel-variabel yang berupa catatan seperti buku-buku, majalah, dokumen, artikel, perkataanperkataan, notulen harian, catatan rapat dan sebagainya.

Kata Kunci: Pendidikan Islam Berkemajuan, Haedar Nashir.

\section{A. PENDAhuluan}

Mutu pendidikan Indonesia ditingkat internasional masih jauh tertinggal dibandingkan dengan negara lain. Bahkan dengan negara tetangga yaitu Malaysia yang menduduki peringkat 65. Berdasarkan data dalam Education For All (EFA) Global Monitoring Report 2011: The Hidden Crisis, Armed Conflict and Education yang dikeluarkan Organisasi Pendidikan, Ilmu Pengetahuan, dan Kebudayaan Perserikatan Bangsa-Bangsa (UNESCO) yang diluncurkan di New York, indeks pembangunan pendidikan Indonesia berada di urutan 69 dari 127 negara yang disurvei. Sistem pendidikan yang dianggap terbaik di Asia adalah Jepang (Amirrachman, 2015: 156).

Jika education development index (EDI) ini sebagai ukuran tentang kualitas pendidikan yang menempatkan Indonesia pada peringkat 69 dari 127 negara, maka ketertinggalan ini tampak cukup memprihatinkan. Tanpa adanya kualitas pendidikan yang tinggi bangsa ini takan mampu bersaing dengan negara lain. Banyak hal yang menjadikan kualitas pendidikan di Indonesia masih jauh tertinggal dari negara lain, 


\section{Sarno Hanipudin, Ahmad Raviki}

berdasarkan analisis kinerja pendidikan di Indonesia juga menyatakan bahwa ada beberapa kelemahan-kelemahan yang mendasar. Pertama, bidang manajemen dan ketatalaksanaan sekolah, termasuk perguruan tinggi. Kedua, bidang pendanaan. Ketiga, berkaitan dengan masalah kultural, dan yang keempat kualitas pendidikan yang rendah, sumber daya manusia yang kurang dan banyaknya penyimpangan moral.

Pendidikan di era global saat ini dihadapkan pada beberapa tantangan. Menurut Zamroni sebagaimana dikutip Amirrachman (2015:157), dampak globalisasi terhadap pendidikan setidaknya tampak pada tiga kecenderungan. Pertama, munculnya kecenderungan dan komoditisasi atas pendidikan. Kedua, globalisasi melahirkan spirit internasionalisasi di lembaga pendidikan, itu berarti pendidikanpun perlu distandarisasi guna meningkatkan daya saing global. Ketiga, munculnya kondisi dimana kemampuan bangsa untuk hidup dalam era global tidak lagi ditentukan oleh modal yang berupa fisik seperti kekayaan, tetapi menggunakan ilmu pengetahuan, jaringan kerja sama dan watak atau moral yang dimiliki bangsa. Oleh karena itu pendidikan merupakan kunci kemajuan, semakin baik kualitas pendidikan yang diselenggarakan suatu masyarakat atau bangsa maka akan diikuti semakin baiknya kualitas masyarakat atau bangsa tersebut. Dengan kata lain, pendidikan dapat menjadi tolok ukur kualitas dan kemajuan suatu bangsa.

Dalam UU RI nomor 20 tahun 2003 sudah dijelaskan secara terang bahwa Pendidikan adalah usaha sadar dan terencana untuk mewujudkan suasana belajar dan proses pembelajaran agar peserta didik secara aktif mengembangkan potensi dirinya untuk memiliki kekuatan spiritual keagamaan, pengendalian diri, kepribadian, kecerdasan, akhlak mulia, serta ketrampilan yang diperlukan dirinya, masyarakat, bangsa dan negara.

Islam memiliki pengaruh besar dalam perkembangan negara Indonesia. Salah satunya yaitu dalam bidang pendidikan. Rendahnya kualitas pendidikan di Indonesia membawa kekhawatiran untuk generasi penerus bangsa. Kekhawatiran sudah termaktub dalam Q.S An-Nisa: 9, yang artinya:

Hendaklah takut kepada Allah orang-orang yang seandainya meninggalkan dibelakang mereka anak-anak yang lemah, yang mereka khawatir terhadap (kesejahtceraan) mereka.oleh sebab itu hendaklah mereka bertakwa kepada Allah dan hendaklah mereka mengucapkan Perkataan yang benar.

Pada ayat tersebut Allah mengharuskan setiap umat untuk tidak meninggalkan generasi yang lemah, tak berdaya dan tak memiliki daya saing dalam kompetensi kehidupan. Dari ayat di atas juga dapat dipahami betapa pentingnya mempersiapkan generasi penerus yang lebih baik melalui pendidikan. 
Adapun firman Allah Swt yang memberi anjuran secara tegas kepada umat Islam agar ada sebagian dari umat Islam untuk memperdalam pengetahuan agama, seperti yang terdapat dalam QS. At-Taubah: 122, yang artinya:

Tidak sepatutnya bagi mukminin itu pergi semuanya (ke medan perang). mengapa tidak pergi dari tiap-tiap golongan di antara mereka beberapa orang untuk memperdalam pengetahuan mereka tentang agama dan untuk memberi peringatan kepada kaumnya apabila mereka telah kembali kepadanya, supaya mereka Alitu dapat menjaga dirinya.

Indonesia merupakan Negara dengan penduduk mayoritas beragama Islam, maka Islampun mempunyai andil besar dalam bidang pendidikan. Dengan melihat fakta bahwa kondisi pendidikan yang masih jauh tertinggal dari negara lain, kini Muhammadiyah (dengan tokoh Haedar Nashir) mulai mengedepankan konsep Islam berkemajuan yang diharapkan mampu untuk memperbaiki dan memajukan pendidikan di Indonesia khususnya melalui Pendidikan Islam. Akan tetapi banyak dari masyarakat yang belum memahami konsep Islam Berkemajuan. Kalimat Islam berkemajuan sedang ramai diperbincangkan sebagai gagasan pembaharuan, yang mana secara tidak langsung akan mempengaruhi kehidupan masyarakat. Tidak hanya itu, konsep Islam berkemajuan juga akan mempengaruhi kemajuan pendidikan Islam di Indonesia. Maka sangatlah penting untuk mengetahui hakikat dari Islam berkemajuan dan konsep pendidikan perspektif Islam berkemajuan.

\section{B. METODE}

Jenis penelitian yang digunakan dalam penelitian ini adalah jenis pendekatan Studi Kepustakaan (kajian pustaka). Jenis metode penelitian ini digunakan untuk membahas mengenai penggunaan media audiovisual yang digunakan untuk meningkatkan motivasi belajar siswa ditingkat sekolah dasar. Studi kepustakaan (Library Research) merupakan suatu studi yang digunakan dalam mengumpulkan data dan informasi dengan bantuan berbagai macam material yang ada di perpustakaan seperti dokumen, buku, majalah, kisah-kisah sejarah, dsb (Mardalis : 1999). Berdasarkan hal tersebut, maka pengumpulan data dalam penelitian ini dilakukan dengan menelaah beberapa jurnal, buku, dan dokumen-dokumen, serta sumber-sumber data atau informasi lainnya yang dianggap relevan dengan penelitian atau kajian. Sumber data yang digunakan dalam penelitian ini berupa buku, jurnal, dan situs internet yang dianggap relevan terkait topik yang telah dipilih. 


\section{HASIL DAN PEMBAHASAN}

Problem pendidikan di tanah air merupakan masalah yang tidak pernah tuntas untuk dibicarakan, ada beberapa masalah pendidikan Islam yang dihadapi, antara lain sebagai berikut.

\section{1) Problem Konseptual-Teoritis}

Ketertinggalan pendidikan Islam di tanah air ini salah satunya dikarenakan oleh terjadinya penyempitan terhadap pemahaman pendidikan Islam yang hanya berkisar pada aspek kehidupan ukhrawi yang terpisah dengan kehidupan duniawi. Dari sisni akan tampak adanya pembedaan dan pemisahan antara yang dianggap agama dan bukan agama, yang sakral dan yang profan. Adanya pemahaman seperti inilah menjadikan ketertinggalan pendidikan Islam di indonesia (Ramayulis, 2006: 342).

a. Secara umum pendidikan sekarang ini tampaknya lebih menekankan pada akumulasi pengetahuan yang bersifat verbal dari pada penguasaan keterampilan, internalisasi nilai-nilai dan sikap, serta pembentukan kepribadian. Di samping itu kuantitas tampaknya lebih diutamakan dari pada kualitas. Persentase atau banyaknya lulusan lebih diutamakan daripada apa yang dikuasai atau bisa dilakukan oleh lulusan tersebut.

b. Pola motivasi sebagian besar peserta didik lebih bersifat mal-adaptif daripada adaptif. Pola motivasi maladaptif lebih berorientasi pada penampilan (performance) daripada pencapaian suatu prestasi (achievement) (Dweck, 1986), suatu bentuk motivasi yang lebih mengutamakan kulit luar daripada isi. Ijazah atau gelar lebih dipentingkan daripada substansi dalam bentuk sesuatu yang benar-benar dikuasai dan mampu dikerjakan.

c. Pendidikan sekarang masih dihadapkan pada berbagai kendala, khususnya kendala yang berkaitan dengan sarana/prasarana, sumberdana dan sumberdaya, di samping kendala administrasi dan pengelolaan. Administrasi serta sistem pengelolaan pendidikan saat ini pada hakikatnya masih bersifat sentralistis yang syarat dengan beban birokrasi. Oleh karena itu persoalan-persoalan pendidikan masih sulit untuk ditangani secara cepat, efektif dan efisien (Abidin, 1998: 126).

2) Problem Pokok Pendidikan

Ada dua masalah pokok yang dihadapi oleh dunia pendidikan di Indonesia saat ini yaitui:

a. Masalah Pemerataan Pendidikan 
Masalah pemerataan pendidikan adalah persoalan bagaimana sistem pendidikan dapat menyediakan kesempatan yang seluas-luasnya kepada seluruh warga Negara untuk memperoleh pendidikan, sehingga pendidikan itu menjadi wahana bagi pembangunan sumber daya manusia untuk menunjang pembangunan.

b. Masalah mutu pendidikan

Mutu pendidikan dipermasalahkan jika hasil pendidikan belum mencapai taraf seperti yang diharapkan. Penetapan mutu hasil pendidikan pertama dilakukan oleh lembaga penghasil sebagai produsen tenagaan terhadap calon luaran. Padahal hasil belajar yang bermutu hanya mungkin dicapai melalui proses belajar yang bermutu. Jika proses belajar tidak optimal sangat sulit diharapkan terjadinya hasil belajar yang bermutu. Berarti pokok permasalahan mutu pendidikan lebih terletak pada masalah pemprosesan pendidikan.

c. Masalah Efisiensi Pendidikan

Para ahli banyak mengatakan bahwa sistem pendidikan sekarang ini masih kurang efisien. Hal ini tampak dari banyaknya anak yang dropout, banyak anak yang belum dapat pelayanan pendidikan, banyak anak yang tinggal kelas, dan kurang dapat pelayanan yang semestinya bagi anak-anak yang lemah maupun yang luar biasa cerdas dan genius.

d. Masalah Relevansi Pendidikan

Masalah relevensi adalah masalah yang timbul karena tidak sesuainya sistem pendidikan dengan pembangunan nasional setara kebutuhan perorangan, keluarga, dan masyarakat.

3) Menghadapi Tantangan Dampak-dampak IPTEK Modern.

Strategi pendidikan Islam dalam mengantisipasi kemajuan IPTEK modern, adalah terletak pada kemampuan mengkonfigurasikan sistem nilai Islami yang akomodatif terhadap aspirasi umat Islam untuk berpacu dalam kompetisi bidang IPTEK di satu pihak dan lain pihak kemampuan psikolis serta pedagogis yang berdaya kreatif untuk mentransfer IPTEK modern itu sendiri. Imilah program minimal Islam yang perlu kita rencanakan dan laksanakan saat ini.

4) Krisis Nilai-nilai dalam Kehidupan Masyarakat.

Manusia mengalami krisis kepercayaan pada kemampuan diri sendiri, yang menjadi gejala-gejala transisi yang sangat rentan (sensitive) terhadap penyusupan nilai-nilai asing yang negative.Krisis nilai demikian demikian mempunyai ruang 


\section{Sarno Hanipudin, Ahmad Raviki}

lingkup yang menyentuh masalah kehidupan masyarakat, yaitu menyangkut nilai suatu perbuatan "baik" dan "buruk", bermoral atau amoral, social atau asocial, pantas atau tidak pantas dan bobot benar dan tidak benar, serta perilaku lainnya.

5) Sistem Pendidikan Modern dan Pergeseran Nilai-nilai.

Posisi lembaga pendidikan saat ini sedang berada dalam arena konflik nilai-nilai yang membawa kepada transisi nilai kehidupan. Nilai spiritual maupun moral etik, yang amat sensitive terhadap sentuhan-sentuhan nilai hedonistic (kenikmatan hidup) materiil dari kemajuan iptek. Sekolah dalam posisi seperti ini, perlu bersikap dalam pelaksanaan tugas pokoknya, yaitu membudayakan umat manusia dengan nilai-nilai ideal. Sehingga mampu menjadi pondasi moral dan spiritual bagi tegaknya masyarakat yang adil dan makmur, sejahtera, bahagia rohaniah dan jasmaniah.

6) Sistem dan Metode Pendidikan Islam dalam Meningkatkan Kualitas Hidup Umat Islam di Indonesia.

Agama Islam yang ajarannya berorientasi kepada kesejahteraan duniawiukhrawi sebagai kesinambungan tujuan hidup manusia, meletakkan iman dan taqwa kepada Allah Swt sebagai landasan kehidupan umat manusia. Pendidikan merupakan proses budaya untuk meningkatkan harkat dan martabat manusia dan berlangsung sepanjang hayat, dilaksanakan di lingkungan keluarga, sekolah, dan masyarakat.

Pendidikan yang dilakukan di sekolah maupun di luar sekolah perlu disesuaikan dengan perkembangan tuntutan pembangunan yang memerlukan bergagai jenis keterampilan dan keahlian di segala bidang.

7) Sistem dan Metode Pendidikan Islam yang Seharusnya.

Strategi pengelolaan sistem pengelolaan Islam seharusnya bertumpu pada antisipasi terhadap timbulnya fenomena kehidupan yang condong kearah mengutamakan sikap dan perilaku yang pragmatisme., dan matrealisme serta individualisme-egoisme. Arah perkembangan yang semakin jauh dalam pendidikan Islam, harus dipandang sesuai tantangan yang penuh perjuangan. Karena itu perlu merencanakan kegiatan pendidikan yang strategis pengembangannya, yaitu dengan mengintregasikan pendidikan Agama dengan pendidikan umum (duniawi) atau memberi nafas keimanan dan ketaqwaan kepada Allah pada setiap bidang studi pendidikan umum disemua jenjang sekolah dan madrasah kita (Arifin, 2003: 60).

Tokoh Islam yang dilahirkan di Bandung, 28 Februari 1958, kesehariannya bekerja sebagai Dosen di FISIPOL UMY. Mantan Sekretaris PP Muhammadiyah periode 2000-2005 ini, Menamatkan pendidikan dasar dan menengah di Bandung. Hijrah ke Yogyakarta untuk melanjutkan studi dan memperoleh gelar S1 dari 
STPMD/APMD Yogyakarta. Sedangkan Gelar S2 dan S3 diperoleh dari Fisipol UGM bidang Sosiologi. Dan dikukuhkan menjadi guru besar UMY. Gelar Profesor Haedar Nashir diperoleh dari Universitas Muhammadiyah Yogyakarta (UMY) tahun 2019.

Tumbuh bersama Muhammadiyah. Ia meniti karier dari bawah hingga pucuk pimpinan. Namanya memang belum sepopuler Amien Rais, Syafi'i Maarif, dan Din Syamsuddin, soal kemuhamadiyahan dan keilmuan tak perlu diragukan lagi karena ia bukan orang baru. Ia bergabung dengan Muhammadiyah sejak tahun 1983 dengan nomor anggota 545549. Pada tahun itu, ia dipercaya sebagai Ketua I Pengurus Pusat Ikatan Pelajar Muhammadiyah. Lalu, pada tahun 1985-1990, kariernya meningkat, Haedar menduduki posisi Deputi Kader PP Pemuda Muhammadiyah hingga menjadi Ketua Badan Pendidikan Kader (BPK) dan Pembinaan Angkatan Muda Muhammadiyah. Puncaknya, pada Muktamar Muhammadiyah ke-47 di Makassar, Jumat pagi, 7 Agustus 2015, Haedar Nashir memperoleh suara terbanyak. Ia berhasil mengumpulkan 1.987 suara, kemudian disusul Yunahar Ilyas sebanyak 1.928, Abdul Mu'ti sebanyak 1.802 suara, Dahlan Rais sebanyak 1.827 suara, dan Busyro Muqoddas sebanyak 1.881 suara. Ia pun resmi menjadi Ketua Umum PP Muhammdiyah 20152020.

Selain aktif dalam organisasi Muhammadiyah, pria yang kerap disapa Haedar ini pun bekerja sebagai Dosen Program Doktor Politik Islam pada program Pascasarjana Universitas Muhammadiyah, Yogyakarta. Profil Haedar Nashir lainnya adalah ia aktif menulis berbagai karya tulis ilmiah baik berupa buku maupun artikel yang dimuat di berbagai media massa. Bahkan, ia pun menjabat sebagai Pemimpin Redaksi majalah Sinar Muhammadiyah. Esai-esainya dapat dinikmati di rubrik "Bingkai" majalah Sinar Muhammadiyah. Selain itu, Haedar juga menulis buku bertajuk "Muhammadiyah sebagai Gerakan Pembaharuan” yang dinilai sangat refrensial.

\section{Konsen Utama Pemikiran Haedar Nashir}

Haedar Nashir adalah seorang tokoh dan cendekiwan muslim indonesia yang telah banyak memberikan sumbangsih kepada negara Indonesia terutama pemikiranpemikiranya.

Salah satu hasil pemikiran Haedar Nashir yaitu tentang konsep pendidikan Islam Berkemajuan. Menurut Haedar konsep pendidikan berkemajuan itu sendiri mencerminkan pendidikan Islam holistik yang mencerahkan. Kemudian lahirlah sistem pendidikan Muhammadiyah dengan tiga lini, yaitu umum, madrasah, dan pondok 


\section{Sarno Hanipudin, Ahmad Raviki}

pesantren modern. Kesimpulannya, jelas bahwa ada proses perubahan dari hasil kritik pendidikan Islam lama atau tradisional (Syifa, 2020).

Dalam ranah pendidikan, pendidikan holistik merupakan suatu metode pendidikan yang membangun manusia secara keseluruhan dan utuh dengan mengembangkan semua potensi manusia yang mencakup potensi sosial-emosi, potensi intelektual, potensi moral atau karakter, kreatifitas, dan spiritual. Tujuan pendidikan holistik adalah untuk membentuk manusia holistik. Manusia holistik adalah manusia yang mampu mengembangkan seluruh potensi yang ada dalam dirinya. Potensi yang ada dalam diri manusia meliputi potensi akademik, potensi fisik, potensi sosial, potensi kreatif, potensi emosi dan potensi spiritual (Megawangi, 2005: 7).

Hal selanjutnya menurut Haedar Nashir adalah Pengembangan pendidikan dan SDM. Jika umat Islam sebagai mayoritas jumlah ingin meraih posisi dan peran strategis yang sama kuat secara kualitas di Indonesia maka jalan utamanya melalui transformasi pendidikan dan pengembangan sumberdaya manusia yang unggul.

"Lembaga-lembaga pendidikan Islam penting diakselerasikan untuk naik kelas, sekaligus memanfaatkan lembaga pendidikan negeri sebagai wahana pendidikan anakanak muslim yang berkualitas untuk melahirkan generasi muslim yang kelak menjadi elite strategis di berbagai institusi penting di ranah nasional maupun global. Ormasormas Islam penting sekali menjadikan pendidikan dan pengembangan sumberdaya manusia sebagai strategi perjuangan dan prioritas utaman dalam merancang peradaban maju ke depan (Adam: 2020).

\section{Pemikiran Haedar Nashir Tentang Pendidikan Islam Berkemajuan}

Dalam buku "Indonesia Berkemajuan" ditegaskan, bahwa Muhammadiyah sebagai kekuatan nasional sejak awal berdirinya pada tahun 1912 telah berjuang dalam pergerakan kemerdekaan dan melalui para tokohnya terlibat aktif mendirikan Negara Republik Indonesia yang diproklamasikan pada 17 Agustus 1945. Muhammadiyah memiliki komitmen dan tanggungjawab tinggi untuk memajukan kehidupan bangsa dan negara sebagaimana dicita-citakan para pendiri bangsa. Kiprah Muhammadiyah tersebut melekat dengan nilai dan pandangan Islam yang berkemajuan.

Pendiri Muhammadiyah sejak awal pergerakannya senantiasa berorientasi pada sikap dan gagasan yang berkemajuan. Sebab, Muhammadiyah sungguh-sungguh percaya bahwa Islam merupakan agama yang mengandung nilai-nilai kemajuan. Islam adalah agama kemajuan (din alhadlarah) yang diturunkan untuk mewujudkan kehidupan umat manusia yang tercerahkan dan membawa rahmat bagi semesta alam 
Munculnya gerakan Islam berkemajuan juga digelorakan pada Muktamar ke-46 tahun 2010 di Yogyakarta, bahwa Muhammadiyah pada abad kedua berkomitmen kuat untuk melakukan gerakan pencerahan. Gerakan pencerahan merupakan praksis Islam yang berkemajuan untuk membebaskan, memberdayakan, dan memajukan kehidupan. Tujuan dari gerakan Islam berkemjuan ini adalah untuk memberikan jawaban atas problem-problem kemanusiaan berupa kemiskinan, kebodohan ketertinggalan, dan persoalan-persoalan lainnya yang bercorak struktural dan kultural, dari sini muncul konsep berkemajuan di segala bidang termasuk didalam pendidikan Islam.

Haedar menjelaskan konsep pendidikan berkemajuan itu sendiri mencerminkan pendidikan Islam holistik yang mencerahkan. Lalu lahirlah sistem pendidikan Muhammadiyah dengan tiga lini, yaitu umum, madrasah, dan pondok pesantren modern. Kesimpulannya jelas bahwa ada proses perubahan dari hasil kritik pendidikan Islam lama atau tradisional. Haedar memaparkan beberapa prinsip untuk meraih pendidikan yang mencerahkan, maka pendidikan itu harus membebaskan, memberdayakan, dan memajukan. Itulah output dari pendidkan modern yang dikenalkan Muhammadiyah (Nashir, 2010: 416).

Dalam ranah pendidikan, model pendidikan holistik merupakan suatu metode pendidikan yang membangun manusia secara keseluruhan dan utuh dengan mengembangkan semua potensi manusia yang mencakup potensi sosial-emosi, potensi intelektual, potensi moral atau karakter, kreatifitas, dan spiritual. Tujuan pendidikan holistik adalah untuk membentuk manusia holistik. Manusia holistik adalah manusia yang mampu mengembangkan seluruh potensi yang ada dalam dirinya. Potensi yang ada dalam diri manusia meliputi potensi akademik, potensi fisik, potensi sosial, potensi kreatif, potensi emosi dan potensi spiritual (Megawangi, 2005: 7).

Manusia yang mampu mengembangkan seluruh potensinya merupakan manusia yang holistik, yaitu manusia pembelajar sejati yang selalu menyadari bahwa dirinya adalah bagian dari sebuah sistem kehidupan yang luas, sehingga selalu ingin memberikan kontribusi positif kepada lingkungan hidupnya. Tujuan pendidikan di Indonesia yang tertuang pada Undang-Undang Republik Indonesia nomor 20 tahun 2003 adalah untuk membentuk manusia yang holistik dan berkarakter. Manusia holistik dan berkarakter merupakan sosial capital bagi perkembangan suatu bangsa (Hanipudin, 2019).

Untuk mencapai tujuan pendidikan Islam yang berkemajuan maka perlu menggunakan pendekatan holistik. Salah satu dimensi dari pendidikan holistik, antar 


\section{Sarno Hanipudin, Ahmad Raviki}

jenjang itu harus mempunyai kesinambungan. Sejak pendidikan Taman Kanak-kanak, sekolah dasar, menengah dan atas sampai perguruan tinggi harus simultan.

Pendidikan Islam berkemajuan memancarkan pencerahan bagi kehidupan. Pendidikan Islam yang berkemajuan akan melahirkan pencerahan secara teologis merupakan refleksi dari nilai-nilai transendensi, liberal, emansipasi, dan humanisasi yang terkandung dalam pesan Al Qur'an surah Ali Imran ayat 104 dan 110 yang menjadi inspirasi kelahiran Muhammadiyah. Secara ideologis, Islam yang berkemajuan untuk pencerahan merupakan bentuk transformasi Al Ma'un untuk menghadirkan dakwah dan tajdid secara aktual dalam pergulatan hidup keutamaan, kebangsaan dan kemanusian universal. Transformasi Islam bercorak kemajuan dan pencerahan itu merupakan wujud dari ikhtiar meneguhkan dan memperluas pandangan keagamaan yang bersumber $\mathrm{Al}$ Qur'an dan Al sunnah dengan mengembangkan ijtihad di tengah tantangan kehidupan modern abad ke 21 yang sangat kompleks (Amirrachman, 2015: 15).

\section{Peran Pendidikan Islam Berkemajuan Terhadap Tantangan Perkembangan Zaman}

Islam Indonesia akan menghadapi dinamika kehidupan baru di abad ke-21 sesuai dengan hukum perubahan. Umat Islam selain tampil sebagai golongan yang membawa pesan damai, toleran, dan propluralitas, juga harus menjadi kekuatan yang prodemokrasi, penegakkan hak asasi manusia, dan civil society. Di samping itu umat Islam Indonesia juga harus menjadi golongan yang unggul di bidang politik, ekonomi, pendidikan, penguasaan ilmu pengetahuan dan teknologi, dan berdaya saing tinggi.

Dalam konteks kehidupan kontemporer yang kompleks itu maka sungguh penting dan relevan kehadiran Islam Indonesia yang berkemajuan. Umat Islam Indonesia yang mayoritas harus tampil sebagai umat berkemajuan, bukan sebagai golongan yang besar sebatas jumlah. Apalah artinya besar secara kuantitas tetapi kalah dalam kualitas. Apakah artinya Islam moderat jika tertinggal dan tangan di bawah. Umat Islam Indonesia yang besar dan moderat harus menjadi golongan besar yang unggul dan tangan di atas. Itulah relevansi kehadiran Islam dan umat Islam berkemajuan di Indonesia (Nashir, 2020).

Haedar menyampaikan dalam pandangan Muhammadiyah, Islam merupakan agama yang mengandung nilai-nilai kemajuan untuk membangun peradaban yang utama dan menjadi rahmat bagi semesta. Inilah yang disebut Islam Berkemajuan atau din al-Hadlarah. "Kemajuan dalam pandangan Islam bersifat multi-aspek baik dalam kehidupan keagamaan maupun dalam seluruh dimensi kehidupan termasuk didalamnya pendidikan Islam yang melahirkan peradaban utama sebagai bentuk peradaban alternatif 
yang unggul secara lahiriah dan ruhaniah. Menurut Haedar, dunia pendidikan Islam tidak boleh kedap, apalagi alergi terhadap nilai-nilai kemajuan zaman yang tumbuh makin dinamis dan progresif.

Menurut Haedar Nashir apabila pendidikan itu konservatif maka dia justru akan teralienasi dari kehidupan modern abad 21. Tapi sebaliknya jika sampai larut dalam kehidupan yang serba bebas, permisif hal ini akan menjadi kelemahan bagi masa depan kita. Untuk mendapatkan kematangan tersebut, maka: pertama, jadikan lembaga pendidikan ini sebagai kekuatan edukasi yang holistik. Kedua, keluarga harus jadi basis yang penting dalam memperkokoh nilai-nilai dan karakter anak sekaligus juga menjadi pusat kemajuan (Nashir, 2020).

\section{Peran Muhammadiyah Dalam Menyongsong Pendidikan Islam Berkemajuan}

Berbicara Haedar Nashir, tentu tidak akan dapat lepas dari Ormas yang dipimpinnya yaitu Muhammadiyah telah berkiprah melewati berbagai fase zaman, dinamika organisasi dilalui dengan keikhlasan dan perjuangan tanpa kenal lelah. Di era penjajahan, Muhammadiyah telah berperan dalam pergerakan kebangkitan nasional menuju kemerdekaan Indonesia. Kemudian ketika awal kemerdekaan Muhammadiyah berperan dalam peletakan fondasi bangsa yang berlandaskan pancasila dan UndangUndang Dasar 1945. Di era Orde Baru, Muhammadiyah terus berkiprah dan berperan dalam pembangunan bangsa. Pergerakan Muhammadiyah dalam lintasan satu abad itu merupakan perwujudan dari pembaruan (tajdid) yang dipelopori Kyai Haji Ahmad Dahlan selaku pendiri gerakan Islam ini. spirit pembaharuan telah melekat dalam gerakan Muhammadiyah generasi awal untuk memahami dan menerjemahkan kembali ajaran Islam ke dalam kerja-kerja kemanusian dan kemasyarakatan yang mencerahkan. Sikap optimis dan pantang menyerah untuk berjuang mewujudkan Islam dalam pencerahan kehidupan.

Menurut Haedar Nashir, Muhammadiyah dalam memahami ajaran Islam melakukannya secara komprehensif. Aspek-aspek ajaran Islam, yaitu aqidah, ibadah, akhlak, dan muamalah duniawiyah (kemasyarakatan), tidak dipisah-pisahkan, meskipun dapat dibedakan satu sama lain. Semua itu merupakan satu kesatuan yang utuh dan harus dilaksanakan dalam kehidupan perseorangan maupun kolektif.

Telah banyak sekali konstribusi Muhammadiyah untuk bangsa Indonesia. Kemajuan bangsa Indonesia tidak lepas dari peran Muhammadiyah. Sejak awal berdiri hingga Muktamar Muhammadiyah ke 47 tanggal 3-7 Agustus 2015 yang lalu di 


\section{Sarno Hanipudin, Ahmad Raviki}

Makasar. Muhammadiyah tetap mengharapkan Indonesia menjadi negara yang lebih maju. Hal ini tercantum dalam tema yang diusung dalam Muktamar ke 47 yaitu “Gerakan Pencerahan Untuk Menuju Indonesia Berkemajuan”. Begitu juga pada Muktamar Muhammadiyah yang ke 46 tahun 2010 di Yogyakarta yang mengusung tema "Islam yang Berkemajuan" yang kemudian secara formal dijadikan substansi tentang pandangan keislaman yang terkandung dalam pernyataan pikiran Muhammadiyah abad kedua (Amirrachman, 2015: 152).

Muhammadiyah menyebut dirinya sebagai gerakan "Islam Berkemajuan" adalah sebagai bentuk respon atas globalisasi yang muncul dalam pergumulan peradaban. Situasi zaman memaksa Muhammadiyah untuk mengejawantahkan visi berkemajuannya dalam praksis gerakan nyata. Meminjam Istilah Din Syamsuddin (2015), berkemajuan menyiratkan adanya keberlangsungan, dan bahkan perkembangan, sebagai usaha yang terus-menerus untuk mencapai tujuan pembangunan berkelanjutan yang bermakna (sustainable development with meaning).

Muhammadiyah telah melakukan lompatan dalam meningkatkan sumber daya insani yang berkemajuan. Muhammadiyah sejak awal berdiri merancang sistem pendidikan Islam modern yang memadukan antara pendidikan agama dan umum serta mengintegrasikan sistem pendidikan sekolah dengan keluarga dan masyarakat.

"Konsep pendidikan seperti ini yang dulu digagas oleh pendiri Muhammadiyah KH Ahmad Dahlan. Idenya sudah sangat maju, beliau sudah memproyeksikan pendidikan sebagai usaha untuk memodernisasi dan memajukan umat dan masyarakat. Melalui konsep tersebut, sebetulnya Muhammadiyah memiliki pondasi di dalam mengkonstruksikan pendidikan Islam bahkan membawa pendidikan nasional yang berkemajuan (Nashir, 2020).

Menurut Haedar, memasuki abad kedua ini Muhammadiyah mengusung tema Islam berkemajuan dimana organisasi yang dipimpinnya itu ingin merevitalisasi gerakan pendidikannya untuk membangun sumber daya insani yang unggul sehingga tumbuh pusat-pusat kemajuan. Muhammadiyah menurutnya ingin melakukan lompatan untuk meningkatkan sumber daya insani yang berkemajuan. "Banyak anak-anak Muslim yang punya potensi sumber daya manusia (SDM) luar biasa, menang berbagai lomba baik nasional maupun internasional. Nah, Muhammadiyah harus mengambil peran memotivasi untuk melakukan revitalisasi dan transformasi pendidikan Islam serta tidak kalah penting membangun pusat-pusat keunggulan pendidikan di luar negeri.

Muhammadiyah memandang bahwa Islam merupakan agama yang mengandung nilai-nilai dan ajaran tentang kemajuan dalam pandangan Islam melekat dengan misi 
kekhalifahan manusia yang sejalan dengan sunatullah kehidupan, karena itu setiap muslim baik individu maupun kolektif berkewajiban menjadikan Islam sebagai agama kemajuan (din al hadharah) dan umat Islam sebagai pembawa misi kemajuan yang membawa rahmat bagi kehidupan

Dalam mewujudkan pendidikan Islam yang berkemajuan Muhammadiyah menggunakan jalan dakwah dan tajdid. Kedua identitas Muhammadiyah tersebut tercantum dalam Anggaran Dasar Muhammadiyah Pasal 1 ayat 1. Muhammadiyah sebagai gerakan Islam bertujuan untuk melaksanakan dan memperjuangkan keyakinan dan cita-cita hidupnya, Muhammadiyah selalu mendasarkan pada prinsip-prinsip ajaran Islam, karena adanya keyakinan bahwa hanya Islamlah ajaran yang mampu mengatur tata kehidupan manusia yang dapat membawa kepada kesejahteraan hidup dunia dan akhirat. Selanjutnya, Muhammadiyah sebagai gerakan dakwah dengan cara melakukan seruan dan ajakan kepada seluruh umat manusia untuk memahami dan mengamalkan ajaran Islam. Dakwah ini dilakukan melalui amar ma'ruf nahi munkar. Sedangkan, Muhammadiyah dikenal sebagai gerakan tajdid karena Muhammadiyah selalu berupaya melakukan koreksi dan evaluasi terhadap berbagai pemikiran dan pengamalan keagamaan dalam rangka pemurnian dalam bidang aqidah dan ibadah yang disesuaikan dengan ajaran Al Qur'an dan As Sunnah. Selain itu Muhammadiyah selalu berusaha untuk melakukan pembaharuan dalam berbagai bidang kehidupan, yang disesuaikan dengan kemajuan zaman dengan tidak meninggalkan prinsip-prinsip Islam

\section{KESIMPULAN}

Dari Uraian diatas dapat disimpulkan bahwa Haedar menjelaskan konsep pendidikan berkemajuan itu sendiri mencerminkan pendidikan Islam holistik yang mencerahkan. Lalu lahirlah sistem pendidikan Muhammadiyah dengan tiga lini, yaitu umum, madrasah, dan pondok pesantren modern. Kesimpulannya, jelas bahwa ada proses perubahan dari hasil kritik pendidikan Islam lama atau tradisional. Haedar memaparkan beberapa prinsip itu. Untuk meraih pendidikan yang mencerahkan, maka pendidikan itu harus membebaskan, memberdayakan, dan memajukan. Itulah output dari pendidkan modern.

Untuk mencapai tujuan pendidikan islam yang berkemajuan maka perlu menggunakan pendekatan holistik. Salah satu dimensi dari pendidikan holistik, antar jenjang itu harus mempunyai kesinambungan. Sejak pendidikan Taman Kanak-kanak, sekolah dasar, menengah dan atas sampai perguruan tinggi harus simultan 


\section{Sarno Hanipudin, Ahmad Raviki}

Dalam ranah pendidikan, pendidikan holistik merupakan suatu metode pendidikan yang membangun manusia secara keseluruhan dan utuh dengan mengembangkan semua potensi manusia yang mencakup potensi sosial-emosi, potensi intelektual, potensi moral atau karakter, kreatifitas, dan spiritual. Tujuan pendidikan holistik adalah untuk membentuk manusia holistik. Manusia holistik adalah manusia yang mampu mengembangkan seluruh potensi yang ada dalam dirinya. Potensi yang ada dalam diri manusia meliputi potensi akademik, potensi fisik, potensi sosial, potensi kreatif, potensi emosi dan potensi spiritual

Haedar menyampaikan, dalam pandangan Muhammadiyah, Islam merupakan agama yang mengandung nilai-nilai kemajuan untuk membangun peradaban yang utama dan menjadi rahmat bagi semesta. Inilah yang disebut Islam Berkemajuan atau din al-Hadlarah."Kemajuan dalam pandangan Islam bersifat multiaspek baik dalam kehidupan keagamaan maupun dalam seluruh dimensi kehidupan termasuk didalamnya pendidikan islam yang melahirkan peradaban utama sebagai bentuk peradaban alternatif yang unggul secara lahiriah dan ruhaniah.

Pendidikan Islam berkemajuan memancarkan pencerahan bagi kehidupan. Pendidikan Islam yang berkemajuan akan melahirkan pencerahan secara teologis merupakan refleksi dari nilai-nilai transendensi, liberal, emansipasi, dan humanisasi yang terkandung dalam pesan Al Qur'an surah Ali Imran ayat 104 dan 110 yang menjadi inspirasi kelahiran Muhammadiyah. Secara ideologis, Islam yang berkemajuan untuk pencerahan merupakan bentuk transformasi Al Ma'un untuk menghadirkan dakwah dan tajdid secara aktual dalam pergulatan hidup keutamaan, kebangsaan dan kemanusian universal. Transformasi Islam bercorak kemajuan dan pencerahan itu merupakan wujud dari ikhtiar meneguhkan dan memperluas pandangan keagamaan yang bersumber $\mathrm{Al}$ Qur'an dan Al sunnah dengan mengembangkan ijtihad di tengah tantangan kehidupan modern abad ke 21 yang sangat kompleks.Menurut haedar nashir apabila pendidikan itu konservatif maka dia justru akan teralienasi dari kehidupan modern abad 21. Tapi sebaliknya jika sampai larut dalam kehidupan yang serba bebas, permisif hal ini akan menjadi kelemahan bagi masa depan kita. 


\section{DAFTAR PUSTAKA}

Al-Syaibani. 1979. Filsafah Pendidikan Islam. Semarang: Bulan Bintang.

Amirrachman, Alpha. Dkk. 2015. Islam Berkemajuan Untuk Peradaban Dunia, Refleksi dan Agenda Muhammadiyah Ke Depan. Bandung: Mizan.

Arifin. 2014. Ilmu Pendidikan Islam. Jakarta: Bumi Aksara.

Hanipudin, Sarno. 2019. Pendidikan Islam Di Indonesia Dari Masa Ke masa. Dalam

Jurnal Matan Vol 1 (No.1) 2019. Error! Hyperlink reference not valid.

Hanipudin, Sarno. 2009. Konsepsi Guru Modern Dalam Pendidikan Islam. Dalam Jurnal

Al-Munqidz: Jurnal Kajian dan Keislaman. Vol $8 \quad$ (No.3) 2020.

https://ejournal.iaiig.ac.id/index.php/amk/article/view/265

Ibnu, Abidin. 1998. Pemikiran Al Ghazali tentang Pendidikan. Yogyakarta: Pustaka Pelajar.

Megawangi, Ratna. 2005. Pendidikan Holistik, Cimanggis: Indonesia Heritage Foundation.

Muhammad, Ali. 2017. Paradigma Pendidikan Berkemajuan. Yogyakarta: Suara Muhammadiyah.

Muhammad Nur, Fatonin. Profil Haedar Nashir. Http://pwmu.co.id diunduh tanggal, 22 Agustus 2020.

Muliawan. 2015. Ilmu Pendidikan Islam :Studi Kasuster hadap Struktur Ilmu, Kurikulum, Metodologi, dan Kelembagaan Pendidikann, Jakarta: Jasa Ungguh.

Muzaki, Akh., dan Kholilah. 2020. Ilmu Pendidikan Islam. Surabaya: Kopertais IV Press.

Nashir, Haedar. Kehadiran Islam Berkemajuan di Indonesia. Error! Hyperlink reference not valid., diunduh tanggal 12 Agustus 2020.

Nashir, Haedar. 2010. Muhammadiyah Gerakan Pembaharuan. Yogyakarta: Suara Muhammadiyah.

Nashir, Haedar. 2020. Pandangan Islam Berkemajuan. Yogyakarta: Suara Muhammadiyah.

Nasution, S. 1996. Metode Research: Penelitian Ilmiah. Jakarta: Bumi Aksara.

Nata, Abidin. 2016. Pendidikan dalam perspektif Al-Qut'an. Jakarta: Kencana.

Nazir, Moh. Metode Penelitian. Jakarta: Ghalia Indonesia.

Ramayulis. 2013. Ilmu Pendidikan Islam. Jakarta: Kalam Mulia.

Rahmat, Hidayat. 2016. Ilmu Pendidikan Islam. Medan: LPPPI. 
Sarno Hanipudin, Ahmad Raviki

Sugiyono. 2015. Metode Penelitian Pendidikan (Pendekatan Kuantitatif, Kualitatif dan $R \& D)$. Bandung : Alfabeta.

https://republika.co.id.muhammadiyah-usung-pendidikan-islam-berkemajuan. diunduh tanggal, 12 Agustus 2020.

Sedarmayanti, Syaifudin Hidayatin. 2002. Metodologi Penelitian. Bandung: Penerbit Bandar Maju.

Yusuf, Munir. 2018. Pengantar Ilmu Pendidikan. Palopo: Lembaga Penerbit Kampus IAIN Palopo. 